\title{
Construction Strategy of Featured Environmental Design Subject Based on Art Design Disciplinary Background
}

\author{
Qionglin Liu \\ School of Art and Design \\ Guangzhou University of Finance and Economics \\ Guangzhou, China 510320
}

\begin{abstract}
The core task of the current national educational reform and development is to cultivate "high quality professional talents and outstanding innovative talents that have firm belief, good character, rich knowledge and excellent ability". With the need of excellent cultural and creative talents in the country and times, environmental design subject in art colleges can construct the professional characteristics by grasping the pulse of the times, relying on the professional background of colleges and universities, and optimizing and integrating the traditional regional cultural resources, as well as to strengthen professional characteristics through personnel training, teacher construction, teaching conditions, achievements transformation, evaluation system and guarantee system, so as to achieve the purpose of cultivating high-quality talents.
\end{abstract}

Keywords - environmental design subject; subject construction; construction objective; construction measures

\section{INTRODUCTION}

In the era of information date, report of the 19th National Congress of CPC has clearly defined the "five-in-one" overall layout and "four comprehensive" strategic layout in accordance with the cause of socialism with Chinese characteristics, and upgrade the Rural Revitalization Strategy and sustainable development strategy to the national development strategy level. "Suggestions on the 13th Fiveyear Plan for National Economic and Social Development by Guangdong Provincial Party Committee" ${ }^{\text {"1 }}$ has put forward to vigorously develop the backbone cultural enterprises and creative cultural industries, cultivate new cultural formats, and make the cultural industry into a pillar industry of the national economy. "Planning Outline of Building Guangzhou into a Strong Cultural City and a Famous World Cultural City (20112020)" has also proposed the development target of taking cultural and creative industries as the pillar, develop the old cultural industry and open new cultural industry, and build a industry development layout in different levels. Cultural construction and talent cultivation are extremely urgent.

Environmental design subject of China came into being from "environmental and interior design subject" opened by

Approved and Passed by Guangdong Provincial Party Committee on November 2015 .
Zhejiang Academy of Fine Arts in April, 1984. ${ }^{2}$ Since the 1990s, with the gradual increase of people's taste toward environmental arts, environmental art was opened in over 1,000 domestic colleges and universities like bamboo shoots after a spring rain. In the "Catalogue of Undergraduate Majors in Colleges and Universities" issued by Ministry of Education in 2012, "design science" was set under the category of "art science", thus separate environmental design from art design. ${ }^{3}$ At present, environmental design in our universities are mainly opened on the basis of other subjects, including architecture, art, agriculture, forestry and so on. With the expansion of enrollment of art students, environmental design is also set up in normal, engineering, comprehensive, agriculture and forestry, and finance and economics universities. Because of the different professional background, although the teaching mode and characteristics are different, the teaching and training objectives are basically the same, and the subject is mainly divided into three environmental directions of outdoor, indoor and landscape.

Environmental design in China connects with many fields like economic life, social formation and planning programming, etc. It occupies a major position in art design education ${ }^{4}$. However, the development time for the subject is short. At present, the statue of the subject in colleges and universities is to meet the needs of the society, and there is no complete and systematic teaching system. Problems like weak links between practice and theory, lack of unity between art and technology, and less coordination between thinking and operation are existing. Compared with the western modern teaching system, such as the German Bauhaus' design education theory system that has achieved the modern teaching mode integrating teaching, research and practice together, environment design subject in China still has great room for development.

\footnotetext{
2 Wu Jiahua, Environmental Art [J]. Hangzhou: New Arts, 1988.4: $42-43$

Ministry of Education. "Catalogue of Undergraduate Majors in Colleges and Universities", 2012.9.

According to the data published by the Ministry of Education in 2005, the major of art design has the largest enrollment number in art subject in our country, and environmental design has the largest talent cultivation number in art design.
} 
Environmental Design Department of Art and Design College of Guangzhou University of Finance and Economics came into being from the space design and research office established in space art design subject in 2008, and began to recruit students formally. In 2012, it was officially renamed as an environmental design major. At the same time, the Department of Environmental Design was established, with two directions of architectural and environmental art design and exhibition design. As the same with the development condition of environmental design in China, the problem of inconsistence between social needs and talents cultivation also exists in our department. The focus of this paper is to explore how to construct the featured subject, establish a design teaching system suitable for local conditions and seek a sustainable development road suitable for the characteristics of the subject by grasping the pulse of the times, relying on the professional background of colleges and universities, optimizing and integrating traditional regional cultural resources.

\section{PROFILE OF ENVIRONMENTAL DESIGN AND PROBLEMS IT FACED}

China promotes social productivity and comprehensive national strength with scientific and technological innovation, which constantly stimulates the enthusiasm of researchers in innovation and entrepreneurship. With the objective of speeding up the construction of a characteristic high-level applied university of Guangdong University of Finance and Economics, environmental design in Art and Design College faces the following opportunities and challenges.

\section{A. Opportunities}

Under the background that the country strongly support the development of cultural creative industry and local cultural creative economy, with the opportunity that Guangdong University of Finance and Economics was designated as the development organization of awarding doctor's degree in Guangdong Province, and under the condition that Art and Design College was awarded first-class subject in art science and has the right to confer master degree for art major, the disciplinary development of Art and Design College centered on the construction of master's degree during the 13th FiveYear Period. As the important support subject in Art and Design College, Environmental Design Department optimizes the inventory resources, develops the direction of development, and shapes the professional characteristics with the advantages of geography and culture, improves the professional level, highlights the characteristics of the subject, perfects the teaching and research evaluation system, makes effective development planning from connotation construction and extension integration, so as to become an important subject and teaching and scientific research institution of high level applied application-oriented university.

\section{B. Challenge}

The major challenges in front of Environmental Design Department are mainly reflected in the following aspects: first, the concept of education and teaching, the mode of education and the mechanism of disciplinary development are facing the challenge of the rapid development of internationalization, informatization and disciplinary development of higher education; second, the talent training mode is facing the challenge of diversified and individualized demand towards talents because of the rapid transformation and development of the nation and Guangdong's economy; third, the level, characteristics and advantages of college running face the challenges of structural adjustment and optimization of higher education in Guangdong, such as the implementation of professional enrollment in 2021.

\section{Thinking ON FEATURED SUBJeCt CONSTRUCTION}

The social competitiveness of colleges and universities is mainly reflected in the "quality of talent training" in higher education. Therefore, "talent training characteristics" is the main dependence of the survival and development of higher education in the competition. The characteristics of personnel training originate from the construction of featured subject. Under the present new situation, featured subject construction is not only an important measure to improve the quality of professional training, but also a major strategic means for colleges and universities to survive and obtain sustainable competitiveness and competitive advantages. Through the investigation and study on some of the national and provincial featured subject construction, it can be seen that colleges and universities should strengthen the featured subject construction and improve the quality of subject construction by four paths of giving full play to subject advantages, emphasizing subject characteristics, deepening connotation construction and strengthening construction management.

Along with the rapid development of economy, science and technology, and the change and development of visual culture, the connotation and form of environmental design have produced intersecting subjects such as "space roaming", "virtual reality", "space information design" and so on out of service to construction, engineering, image and information.

Guangdong University of Finance and Economics, based on the background of finance and economics subject and the regional advantages of international exhibition business district, shows the running characteristics of "integration of commercial and law, practice of entrepreneurship, diversification and coordination". We should adhere to the personnel training concept of "people-centered education and all-round development; teaching students in accordance with their aptitude, learning in order to practice", and cultivate advanced professional talents with fine ideological and moral qualities, scientific spirit, humanistic quality, professional knowledge and international vision, and being bold in making innovations.

In view of the development trend of the times and the goal of college development, the Department of Environmental Design draws on the experience of subject construction at home and abroad, and leads the original traditional subject construction to the modern, multilevel, less and more refined discipline system based on the "financial, commercial, and business subject" of Guangdong University of Finance and Economics. While improving the level of educational informatization, we should consolidate professional 
characteristics from three aspects: regional culture, geographical advantages and social services.

\section{A. Inherit the Cultural Heritage of the Traditional South of the Five Ridges}

Art and Design College of Guangzhou University of Finance and Economics situated in Guangzhou, the cultural center of South of the Five Ridges, is a regional university. Its major task is to cultivate high level applied talents. The traditional art of South of the Five Ridges has a profound historical precipitation, and the culture embodies the unique artistic design ideas of South of the Five Ridges and the consciousness of aesthetic thinking and modeling. It also has the popularity of the local people's extensive aesthetic cognition and application, and has the material practical functional value, such as the cultural representation in construction space, building materials and architectural colors. The introduction of traditional cultural characteristics of South of the Five Ridges into professional teaching can realize the transformation of modern characteristics of regional education.

\section{B. Construction of Times Pattern with Geographycal Advantages}

Guangdong University of Finance and Economics is located in the core area of Pazhou International Exhibition Business Circle of China Pearl River Delta that integrates multibusiness formats of manufacture, electronic commerce, internet industry and convention and exhibition, where is the frontline of international information of various international trade fairs and special exhibitions, enjoys advantages geographical position and business advantages. Through attracting internet enterprises and e-commerce headquarters' participation into the construction and development of the teaching and scientific research of environmental design, such as learning exchange, theoretical research, project practice, and enterpreneurship and employment and other cooperation mode, we can cultivate high end design personnel with both traditional culture and keen sense of the times.

\section{Social Service to Make Contribution to Local Economy}

In response to the call for enhancing the social service capacity proposed by "National Medium and Long Term Education Reform and Development Program (2010-2020)" and "Guangdong Provincial Medium and Long Term Education Reform and Development Program (2010-2020)", and improving the application research and social service capacity proposed by "Guangdong University of Finance and Economics 13th Five-Year Development Plan", we should take full advantage of the geological location of Guangdong University of Finance and Economics that situated in Pazhou Convention and Exhibition Center and Internet Innovation Cluster, and fully play environmental design's function of combination of production and teaching relying on the related subjects of the university, taking the initiative to carry out the responsibility of promoting the development of the local economy, creating a professional bright spot, expanding the growth point of the new curriculum, and making rational and unified layout. We will construct a design industry theory and practice system that centered on environmental design and project planning, programming, landscape, architectural design and exhibition design are interdependent, and conduct high level talents related scientific and teaching research by the path of government vertical and enterprise horizontal, and thus promote the transform and improvement of education in concept and technology.

\section{COnstruction Measures of FEATURED SubJect}

Environmental design is an important supporting subject in the college of art and design. The corresponding measures and methods should be implemented in six aspects: position of personnel training, construction of teachers' team, teaching conditions, achievements transformation system, evaluation system and quality assurance system in "Fig. 1".

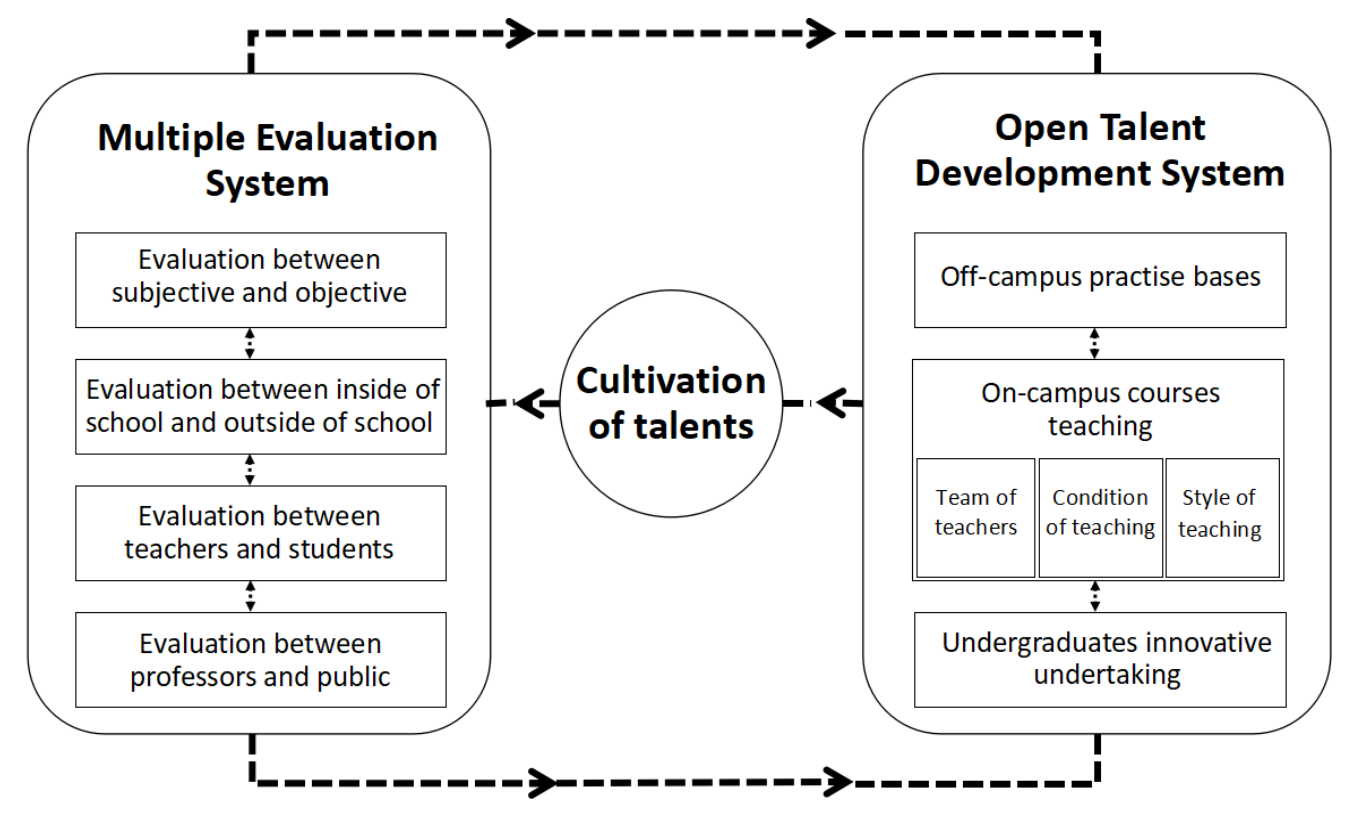

Fig. 1. Mode of talents cultivation. 


\section{A. Perfecting Mode of Talents Cultivation}

At present, the talent cultivation mode of environmental design is market oriented, which meets the existing market demand in a certain stage, but lacks the concept of consciousness change and the mastery of necessary professional knowledge brought by the age of intelligence and modern information technology. Through spatial information collection and large data sharing, the corresponding course teaching can be carried out on the artificial intelligence parameterized platform. On the basis of maintaining the original traditional teaching mode, the talent cultivation mode of environmental design with information technology features can be constructed.

\section{B. Teachers' Team Construction of "Double Teachers and Dual Ability"}

The present knowledge structure, title, academic degree, and age structure of the environmental design teachers' team are well balanced to meet the needs of high level application type and research type talents cultivation with interdisciplinary knowledge structure. However, in the era that environmental design industry is entering the large data sharing platform (BIM) and parameterized design, the existing teaching team lacks professional training for large data and artificial intelligence. Therefore, the key construction objective of teaching team is to realize the construction of a teaching team with the combination of the traditional professional design ability and the mastery of frontier information technology, perfect the teacher cultivation platform of "double teachers and dual ability", strength the cooperation between the environmental design subject and the government, industry and enterprises, and build up a number of stable "double teachers and dual ability" teachers training and practice platform.

\section{Perfecting Teaching Conditions}

Continuously optimize and improve the teaching conditions, such as teaching funding, professional laboratory construction, professional books collection and practice base construction. The practice base is mainly based on industry, study and research, with the principle of resource sharing, complementary advantages and optimized combination.

\section{Achievements Transformation System}

The two sides should actively carry out scientific and technological research and transformation of scientific and technological achievements, and strive to promote the integration of science and technology with the economy. Enterprises should actively formulate policies for the transformation of scientific and technological achievements and support policies for innovation and entrepreneurship so as to attract the scientific and technological achievements of the Department of Environmental Design to achieve transformation in enterprises. Department of Environmental Design should take enterprises as the important transformation base of the latest scientific and technological achievements, encourages and supports teachers and post-doctoral researchers to carry out scientific research activities in enterprises, and use their own technical advantages to promote the development of science and technology, new materials and so on in enterprises.

Environmental design and enterprises can work together in building "College and Enterprises Collaborative Design Innovation Center", and carry out in-depth cooperation like talents training and recruitment, education and training of enterprises management personnel, tutor appointment, practice and the establishment of special scholarship, fully displaying the advantages of the combination of production and teaching in modern industry. The talents cultivation needs of our department can be fully meet through the cooperation of college and enterprise.

It is intended to transform teaching achievements into works or experience promotion. In order to ensure that the teaching of both the required courses (including the basic subject and the required courses) and the elective courses can be deepened according to the plan, the teaching materials of the courses should be formulated in combination with the subject characteristics.

\section{E. Perfecting Evaluation System}

Multi-dimensional evaluation system: combine subjective evaluation and objective evaluation, draw reference from in campus evaluation and out of campus evaluation, make complement from teacher evaluation and student evaluation, integrate academic and non-academic evaluation. The multidimensional evaluation system jointly examines the realization of training objectives for environmental design professionals.

\section{F. Strengthening Quality Assurance}

The teaching quality supervision system in college is carried out through the improvement of various teaching quality standards and the establishment of teaching quality evaluation and feedback mechanism. We should also improve the quality consciousness of teachers to promote the improvement of teaching art and teaching level.

\section{CONCLUSION}

Taking the featured construction of environmental design subject of Art and Design College of Guangdong University of Finance and Economics as the example, this paper discusses how to make best use of the advantages and bypass the disadvantages, seize opportunities and develop professional direction to highlight the professional characteristics in complementing with the advantageous subject in the university under the background of current policy and regional development trend. In addition, with the concept of "integration of college and the city", the academic advantage of the university think tank is brought into play, forming a benign cycle and synchronous development of subject development and regional construction, and achieving the purpose of cultivating high level practical applied talents for local cultural creativity and economic development.

\section{REFERENCES}

[1] Wu Jiahua, Environmental Art [J]. Hangzhou: New Arts, 1988.4 
[2] Lin Guangsi, Review and Prospect of Environmental Design Education. Chongqing: Higher Education of Construction, 2014: 23 (5).

[3] Zhen Zhen, Take the Road of Featured Subject Construction and Strive for Survival and Development in Competition [J]. Beijing: China Metallurgical Education, 2006, (3).

[4] Yang Xinhai, Xu Zongning, Fu Baochuan, Zhang Xiongwu. The Approach to the Construction of Featured Subject of University Undergraduate Course [J]. Taiyuan: Educational Theory and Practice, 2011, (12).

[5] The Sixth Disciplinary Review Group of the Academic Degrees Committee of the State Council. A Brief Introduction to Degree Awarding and Talent Training First Class Subject [M]. Beijing: Higher Education Press, 2016.

[6] Jin Daiqiang, Han Ran. Study on the Art and Design Education of Universities in Guangdong [M]. Guilin: Guangxi Normal University Press, 2010. 